\title{
GCU
}

Glasgow Caledonian

University

University for the Common Good

\section{Analysis of writing programmes for academics: application of a transactional and systems approach}

Kempenaar, Larissa; Murray, Rowena

Published in:

Studies in Higher Education

DOI:

10.1080/03075079.2017.1329817

Publication date:

2018

Document Version

Author accepted manuscript

Link to publication in ResearchOnline

Citation for published version (Harvard):

Kempenaar, L \& Murray, R 2018, 'Analysis of writing programmes for academics: application of a transactional and systems approach', Studies in Higher Education, vol. 43, no. 12, pp. 2371-2384.

https://doi.org/10.1080/03075079.2017.1329817

\section{General rights}

Copyright and moral rights for the publications made accessible in the public portal are retained by the authors and/or other copyright owners and it is a condition of accessing publications that users recognise and abide by the legal requirements associated with these rights.

Take down policy

If you believe that this document breaches copyright please view our takedown policy at https://edshare.gcu.ac.uk/id/eprint/5179 for details of how to contact us. 


\title{
Analysis of writing programmes for academics: Application of a transactional and systems approach
}

\author{
Authors \\ Dr Larissa Kempenaar, School of Health and Life Sciences, Department of Psychology, Social Work \\ and Allied Health Sciences, Glasgow Caledonian University, Glasgow, United Kingdom \\ Professor Rowena Murray, School of Education, University of the West of Scotland, Ayr Campus, \\ United Kingdom
}

\begin{abstract}
In an international culture of performance based funding systems for Higher Education Institutions, (HEIs) research productivity and output are essential for the ability of HEIs to continue. While many institutions have performance targets for the next performance assessment, few institutions have an operational strategy for how staff are to produce research publications. A transactional and systems approach to academic writing may be helpful in identifying how academics' structures and beliefs influence their writing productivity. This paper aims to provide an overview and analysis, using a transactional and systems approach, of a selection of theory-based writing programmes available for academics. The authors summarise the strengths and weaknesses of each these programmes and demonstrate the gap in academic writing programmes which currently exists, based on the transactional and systems approach. The paper provides recommendations in terms of strategic development to support academic to increase their research and scholarly output.
\end{abstract}

Key words Academics' writing, transactional model, systems model, behaviour, perceived control 


\section{Introduction}

There is currently a lot of academic debate around the merits and pitfalls of performance based funding systems (PBFS) and the performativity which is now commonplace within higher education (e.g. Hicks 2012). This is offset by debates regarding the assumption of the validity of academic meritocracy (e.g. Nielsen 2015). Independent of which side of the debates you are on, the current reality for academics is that research or scholarly output is essential for career progression and the future of HEI funding. However, balancing the multiple demands of the academic role means that academics can find it difficult to prioritise writing, particularly if writing time is not included in plans of work. Furthermore, it is becoming more and more difficult to get published in peer reviewed journals. This provides an additional challenge for academics, as rejection or 'accepted pending changes' of an article means additional pressure on already limited time, as more time is required to get an article published in a peer reviewed journal. While many institutions have performance targets for the next performance assessment, they are less likely to have an operational strategy for the process whereby research publications are produced. This is particularly lacking for staff who are not specifically identified as research active or aligned with research centres. The lack of an operational strategy often means that the offer of interventions or programmes for academic staff are limited. While interventions are available, evidence of their effectiveness to create sustained changes in writing practices and/or writing cultures is limited and what evidence there is frequently lacks underpinning theory or conceptual frameworks.

Kempenaar and Murray (2016) presented a transactional and systems model for making sense of the writing behaviours of academics. This approach is based on a behavioural process model (Van Egeren 2000) integrated with a transactional model of stress (Lazarus and Folkman 1984) and is situated in a systems model, based on Bronfenbrenner's ecological systems theory (1979). The transactional model considers behaviour to be based on the cognitive appraisal by the individual of a particular situation. These appraisals or beliefs can be categorized based on the relationships between four domains: the academic, the environment, their behaviour and the desired outcome. The beliefs based on these four relationships can be summarised as follows: the academic will only write if they believe that they personally can perform writing behaviours (performance belief), they are able to actively change the environment to produce writing (process belief), to achieve their writing goals (prospect belief). In turn they believe that achievement of these writing goals, i.e. publications, will benefit them personally in some way (profit belief), such as a personal sense of achievement, professional status or career progression (see Kempenaar and Murray 2016 for more examples of how this applies to academic writing). 
The academic must have sufficient beliefs in each of these domains to move into action. The authors argue that this process of appraisal of writing does not take place in isolation (Kempenaar and Murray 2016). They argue that it involves a process of appraisal of a particular person-environment relationship. While using this transactional approach goes some way in making sense of an academic's writing behaviour, including a systems approach recognises that writing behaviour is not solely based on the individual's internal cognitive processes, but it is embedded in a structure or system. The authors proposed Bronfenbrenner's ecological systems theory (1979) to make sense of the structure in which the academic is embedded. This model embraces the different systems in which the individual is sited, including the microsystem (the immediate academic environment in which the person is situated such as colleagues and line management), mesosystem (the interconnections between people in the microsystem), exosystem (the relationship between line management and the university's higher levels of management, targets, policies and strategies) and macrosystem (academia as a culture with its values and history, but also includes the larger society in which it is embedded).

Some would argue that, as writing is considered mandatory within academic systems, individual choices and values are secondary to explaining academics' writing behaviours. On the other hand, many programmes which support academics to write only address the individual's skills and attitudes. Kempenaar and Murray (2016) propose that when attempting to get a better understanding of academics' writing behaviours (or the absence of them), it is important to consider both the system in which the academic is embedded and the individual's beliefs regarding their writing behaviours, in order to develop ways to support and develop academics to change their writing behaviours. The relationship between these two approaches; however, is not linear, but intrinsically complicated.

While our first paper (2016) outlined the proposed models, in the current paper we aim to apply these models to provide an understanding of, and bring together, a selection of existing writing programmes for academics and some of the concepts underpinning these programmes. This will assist academic staff and those at strategic levels to identify approaches suitable for the institution, and the individuals within it. This may facilitate the individual academic to achieve their personal writing goals and obtain a sense of achievement in the academic context. In addition, universities will benefit in terms of the development of strategies to support academic staff to produce research output, meet research performance based criteria and ensure the institution's financial survival.

Interventions for academic writing were first systematically reviewed by McGrail, Rickard and Jones (2006), who categorised writing interventions into writing coaching and mentoring, writing support groups, writing courses and writing retreats. All these interventions have something to offer in terms of supporting and developing academic staff to produce research or scholarly papers. McGrail, 
Rickard and Jones (2006) came to the conclusion that support groups and mentoring were more beneficial than writing courses. Structured interventions were found to be more beneficial than unstructured interventions and regular, ongoing programmes were most beneficial. However, no attempt was made to provide a framework or theory which could explain the benefits of these interventions. A second systematic review by Galipeau et al. (2015) of 'writing for publication' interventions for medical and allied health professionals included writing coaching and mentoring, face-to-face or online writing workshops and courses, group meetings/support groups and a faculty development programme. They concluded that studies generally found an increase in academics' publication rates following participation in the writing intervention. One study found that manuscript quality improved following an online writing for publication programme. Again, like McGrail, Rickard and Jones (2006), Galipeau et al. made no attempt to provide a framework or theory to explain the benefits of these interventions.

In this paper, we aim to review a range of programmes for academic staff which have been published in Anglophone, international journals. While there are various studies on the benefits of writing programmes (e.g. Dickson-Swift et al. 2009; Herman, Abate and Walker 2013; Johnston et al. 2014; Paliadelis, Parker and Parmenter 2015; Pololi et al. 2004), these studies are not based on conceptual or theoretical frameworks. To further our understanding of the effectiveness of writing interventions, we only included papers in this review which employed a theoretical or conceptual framework to underpin the writing intervention. In this paper, we will analyse these studies and apply the transactional and systems model to provide a more comprehensive understanding of the benefits and limitations of these interventions and underlying frameworks.

This paper is not intended to be a comprehensive review of writing programmes available for academics; rather, it aims to demonstrate, by analysing examples of theory-based writing interventions, how the transactional and systems approach can be a helpful way of pulling together existing theories and frameworks. Furthermore, it provides recommendations in terms of planning, designing and implementing writing interventions for academics which suit both individual academics and their institutions.

\section{Writing Programmes}

The models we will analyse in this paper include the academic literacies framework (Lillis, Magyar and Robinson-Pant 2010), communities of practice (Dwyer et al. 2015), situational leadership (Baldwin and Chandler 2002), Servant Leadership (Jackson 2009), leadership through Containment (MacLeod, Steckley and Murray 2012), the stages of change model (Murray and Thow 2014) and 
engagement (Murray 2013). We will describe and analyse each model and explore how these have been applied in the studies in turn before synthesising the key points from these models within the transactional and systems approach and, finally, providing recommendations (see Table 1). 
*** INSERT TABLE $1 * *$

\section{Academic literacies}

Lillis, Magyar and Robinson-Pant (2010) presented a model of mentorship by editorial staff and reviewers of a specific international journal to address inequality in publishing based on an academic literacies approach. The academic literacies approach (Lillis and Scott 2007) views literacy as a 'social practice' rather than merely being skills based, which runs against discourses of writing support as 'skills acquisition'. Lillis, Magyar and Robinson-Pant devised an intervention in the United Kingdom using an academic literacies approach to address the impact of performance based funding systems around evaluations of Anglophone centred journals which encourages inequality in publication rates. The aim of their intervention was to increase access to resources to successfully publish in an Anglophone centred journal, while also facilitating reflection of the editorial process for the journal. This intervention, therefore, did not focus on skills acquisition, but on increasing awareness of the culture and the controversy surrounding the dominance of publishing in international Anglophone academic journals.

Although we are aware that this is not always defined as 'skills' in the technicist sense, when viewing this programme from a transactional and systems approach, we argue that the authors considered both skills and the cultural aspect of the writing process. Performance beliefs relating to writing ability were addressed by the practical aspects of the workshop in terms of writing and rewriting an abstract based on feedback and the hands-on support from mentors and facilitators. Process beliefs were addressed by clarifying the style and nature of writing required. Furthermore, the study aimed to raise awareness of the implicit rules and values of the journal emphasizing that process beliefs are culturally sited in macrosystem(s). The programme not only enhanced the authors' beliefs and systems, but journal editors and reviewers were challenged in their views of publishing. The programme therefore affected not only the beliefs of the author but also changed the macrosystem of the publication itself. Furthermore, while journal editors and reviewers could be considered as the macrosystem in terms of influencing the culture of academia through publishing decisions, in this study the relationship between the individual and the macrosystem is challenged and altered to become a microsystem.

Even though the programme was targeted at non-Anglophone authors, the aims and components of the programme extend to any academic aiming to get published, as several studies have identified the hidden rules and values of journals, i.e. a negative process belief in terms of clarity of the process influenced by the macrosystem which leads to low prospect beliefs (Reidpath and Allotey 2010). 


\section{Communities of practice}

The communities of practice model, like the academic literacies approach, recognizes that practice is socially situated. The communities of practice model (Wenger 1998; Wenger, McDermott and Snyder 2002) was used by Dwyer et al. (2015) to develop and evaluate the impact of residential writing retreats in Australia. Communities of practice arise where a group of people have a shared goal for developing their practice through interaction. The development of a community of practice is reflected in the micro- and mesosystem of the behavioural systems model, as it is not merely the relationships between the individual and other academics, but, in addition, it is determined by the way academics relate to each other.

Dwyer et al. (2015) devised a programme to develop a community of practice based on the shared goal of academic writing. The developing sense of community and ownership would enhance the internal motivation of the group members to write, rather than this being compelled by external drivers. A retreat was facilitated on an island off the coast of Australia. Following the retreat, all those involved met to identify achievements and identified further needs to sustain the writing and sense of community, which included a writing group and a subsequent retreat.

This programme of interventions mirrors the academic literacies approach in that it addresses both the skill level of the individual, but recognises that writing is a social practice. The person's process and prospect beliefs are addressed in writing by offering structured workshops on academic writing. Performance beliefs were increased by providing participants with time to write and through goal setting and monitoring. Interestingly, feedback suggested that participants wanted more time to write and fewer taught sessions during the retreat. This suggests that while taught sessions were viewed as helpful, participants favoured the development of performance beliefs, rather than process and prospect beliefs. Like Lillis, Magyar and Robinson-Pant (2010), the facilitators were journal reviewers and editors, which meant that again that the structure for individuals changed by changing the relationship with the macrosystem into a microsystem. The key factors which made facilitation positive were the experience and knowledge of the facilitators, but also the person-centred approach taken by the facilitators, which highlights the importance of the nature of facilitation (mesosystem). The peer group was perceived as supportive and facilitated a sense of obligation to each other, suggesting the mesosystem had evolved as a result of the writing retreat and the developing community of practice. In terms of a community of practice the evaluation suggested that the secluded location and facilitation contributed to the development of a network of like-minded individuals (micro and mesosystem). 


\section{Leadership models}

A number of papers have used leadership models to underpin writing groups or retreats, and to provide coaching or mentoring programmes. Leadership models include situational leadership (Baldwin and Chandler 2002), servant leadership (Jackson 2009), and containment theory (MacLeod, Steckley and Murray 2012).

\section{Situational leadership}

Baldwin and Chandler (2002) responded to the need for an increase in publications for a group of academic nurses in the US. They used the situational leadership II model (Blanchard, Zigarmi and Zigarmi 1985), which suggests that leadership should meet the needs of the individuals in the group. In this case they argue that most academics have the knowledge and skills to write or have access to develop these, but have a need for support and encouragement to cope with the emotional and social challenges of writing. This warranted the need for relational leadership behaviour. A coach was hired for staff to provide mentoring for staff to publish. Based on Evered and Selman's (1989) framework, a coach empowers by providing 'validation and encouragement', 'as well as dialogue, feedback and guidance'. This style of coaching, like motivational interviewing (Murray and Thow 2014) aims to facilitate the individual to 'find their own way towards their goal'.

Besides the coaching approach to acknowledge, create and empower, the coach provided informal support, including information, instrumental, emotional and appraisal support which Baldwin and Chandler based on House (1981, cited in Baldwin and Chandler 2002). The Dean of the Faculty supported staff with unlimited time to write the manuscripts and continually encouraged staff to use the services of the coach. This illustrates that while providing coaching as a way of providing a microsystem that is supportive and facilitating, an enabling exosystem in this instance was essential.

The writing coach programme intervened at a number of levels within the transactional and systems approach. The faculty Dean provided a supportive and enabling exosystem. The coach provided a positive microstructure. Within these systems the staff member was mentored to develop their performance beliefs by enhancing their process and prospect beliefs. As the individual and the coach celebrated all achievements of progression and goals, positive profit beliefs were developed, which boosted their ability to continue in the process. The microsystem which is described here only related to the relationship with the coach, but the authors argue that the experience of a positive supportive relationship may have influenced faculty members and therefore the mesosystem. The authors suggest the potential use of peers to provide this kind of support. This is reflected in the Murray and Thow (2014) intervention which used peers to provide support. This will be discussed later. 
Jackson (2009) used the Servant Leadership model as the basis for 3-day residential writing retreats for academic and clinical nurses in Australia. The idea behind Servant Leadership is the notion that a leader is a servant first and aspires to be a leader second (Spears 2004). This translated in Jackson's study to using mentors as servant leaders, who were selected to provide and inspire a culture of trust and confidence in a group of novice writers. The Servant Leader model is an example of developing a positive microsystem whereby those immediately surrounding the novice writer, encourage trust and confidence. This intervention clearly aimed to provide a positive microsystem for the individual. Participants in turn experienced the exosystem as supportive of their writing behaviours in terms of money and time. In addition, the retreats also aimed to address the novice writers' control beliefs by focussing on the development of skills and confidence (performance and process belief) to undertake productive writing activities. As all participants were supported in the writing process and the submission of the writing, novice writers were able to succeed in submitting a piece of writing for a journal or book, and so they experienced a positive outcome of their efforts, resulting in increased prospect beliefs.

\section{Containment}

Murray and Newton (2009) introduce the concept of the 'structured' writing retreat in the United Kingdom, where fixed time slots are dedicated solely to writing. The fixed structure of writing and discussion slots is based on the recommendation by McGrail, Rickard and Jones's (2006) systematic review that structured interventions for academic writing have been found to be more beneficial than unstructured or informally structured support. This builds on the work by Grant and Knowles (2000) and Moore (2003). The time slots are rigorously upheld by the facilitator in order to avoid slippage and task avoidance or deviation. This aspect of this form of retreat, while challenging for some, is generally appreciated by those attending (Murray and Newton 2009). MacLeod, Steckley and Murray (2012) reviewed the role of this leadership at structured writing retreats by using Containment Theory (Menzies-Lyth 1988). Containment Theory is based on the premise that clarity of task (in this case writing) provides containment for the writer. Containment therefore relates to having positive, strong control beliefs and the value attached to task clarity by the structure the academic is embedded in. Three different domains were identified relating to containment: emotional, epistemological and organisational containment (MacLeod, Steckley and Murray 2012). Emotional containment refers to making potentially unthinkable and unmanageable feelings, thinkable and manageable. In other words, enhancing what could be described as performance beliefs. Task primacy and emotional containment are enhanced in the structured writing retreats through physical and cognitive disengagement. Writing retreats take place in an isolated, physical environment, which is highly 
structured in terms of the timetable, which enables task primacy, where writing becomes 'thinkable and manageable'. The development of emotional containment is clearly related to the development of performance and process beliefs, i.e. knowing what needs to be done and believing that you can put this behaviour into practice (MacLeod, Steckley and Murray 2012). Epistemological containment was described as participants making sense of their own writing and the position of writing within their academic roles (profit belief). The authors suggest that the explicit primacy of writing tasks helped participants to make sense of the writing purposes, practices and tasks within their roles as academics. Organisational containment refers to the organisational practices, policies and procedures that contribute to organisational, professional and managerial clarity. Unfortunately, academics are sited in micro and exosystems that may not always be clear about the primacy of tasks. This means that if there is perceived ambiguity about the primacy of writing (prospect belief) and the benefits of meeting this demand (profit belief), the individual is less likely to perform behaviours leading to writing. In addition, when the individual does write, they may feel frustrated and anxious about balancing the multiple demands of the academic role (MacLeod, Steckley and Murray 2012); feelings associated with weak prospect beliefs.

Finally, organisational containment is provided by releasing time and financial support to facilitate academics' disengagement from other academic duties and engagement with writing within work hours. This means that Structured Writing Retreats provide clear organisational containment which creates an exosystem that legitimizes writing by supporting positive and productive writing practices (MacLeod, Steckley and Murray 2012).

\section{Stages of change}

Murray and Thow (2014) developed an approach called the 'writing meeting', based on the principles of motivational interviewing and the stages of change model. These stages are pre-contemplation, contemplation, preparation, action, maintenance and (re)lapse (Miller and Rollnick 2002, cited in Murray and Thow 2014). Motivational interviewing is an approach to facilitate a person to change their decisional balance towards altering their behaviour. Through weighing pros and cons of behaviours and using social support, the individual aims to move along the stages of change. The decision to change behaviour rests with the individual, resulting in a greater likelihood of maintaining the desired behaviour change by aligning personal beliefs and values supporting the behaviour. The writing meeting is facilitated by a peer who is empathetic, non-judgemental and accepting of the person's decision. This approach is similar to that of the writing coaching presented by Baldwin and Chandler (2002). 
The stages of change model seems to reflect the transactional and systems approach to writing behaviour. Viewed from this perspective, it is clear that the individual's decisional balance appears to relate to the strength of different control beliefs. The benefits of writing, for example, a sense of satisfaction and an outlet for creativity, seem to relate to the academics' profit beliefs, in terms of the personal achievement associated with the outcome of writing. Interestingly, while the institutions' 'profits' are in terms of Key Performance Indicators and Research Assessment frameworks, this was not the case for the individual academics. The negatives associated with 'not writing', such as a sense of feeling 'overwhelmed' with the task through the stressful writing process and a lack of institutional support, appear to relate to the negative responses from the micro- and exosystems. In contrast, the 'hardship' of writing can be seen as a negative performance belief.

Participants learned to develop more realistic goals, and while some perceived goal setting as performative, the writing meeting provided a space to negotiate and work through the writer's ambivalence towards writing. The celebration of achievements with peers was described as 'peerformativity' (Murray and Thow 2014). In terms of social support, the findings suggested that the conversation itself developed the writer's thinking processes. The meetings not only provided a means of sharing success but also alleviated the negative aspects of writing, such as perceived loneliness.

This supports the notion of the importance of the microstructure to provide a space to develop thinking about writing, but also for sharing both positives and negatives. The writing meeting also appeared to work as a space where individuals moved the locus of decision making about their writing from the perceived exosystem, seen as prohibitive to writing, to individual process beliefs on how to manage writing within existing systems. This was also reflected in discussions of how the values of the exosystem in terms of performativity were aligned with the individuals' desires to write. Furthermore, the writing meeting appears to support the notion that an individual's writing behaviour can be positively facilitated by structuring the microsystem.

\section{Engagement}

The structured approach to developing social interconnections, and its importance for the effectiveness of writing retreats, is also reflected in Murray's (2013) concept of social disengagement, the process of devoting less energy to other people, by not responding to their demands and dealing with actual, or anticipated, negative responses to this approach. Social engagement, as experienced during Structured Writing Retreats, is described by participants as the process of becoming embedded in a 'microculture' of writers who are supportive of each other, and therefore provide a means of legitimizing writing (Murray 2013). Another key aspect of Structured Writing Retreats is that they are 
a space and time away from work and family life, where writers are enabled to disengage, in order to engage solely with writing. Disengaging from other tasks and roles as a means of enabling engagement with writing appears strongly connected to the concepts of performance and process belief, i.e. knowing what needs done and the personal ability to do it. Murray (2013), using a framework analysis of interview transcripts with retreat participants, identified three types of disengagement: physical, social and cognitive. Both physical and cognitive disengagement appear to express participants' process beliefs. Physical disengagement refers to the requirement of removing oneself from the office space and clearing the diary. Cognitive disengagement, which was considered by participants to be the hardest to achieve, takes place when writers cognitively removes themselves from other responsibilities, whether at work or at home. Both types of disengagement are viewed as requirements to enable the writer to engage in writing, i.e. process beliefs. On the other hand, Murray summarised cognitive engagement as a way of legitimizing writing, i.e. an increased belief that the immediate environment (i.e. the microsystem) can not only be manipulated to facilitate writing, but in fact becomes conducive to writing.

While the performance and process beliefs were more straightforward for physical disengagement, i.e. it is easier to identify how to do this and identify the ability to do this, this was less clear for cognitive disengagement. In other words, while participants had strong process beliefs in terms of needing to become cognitively disengaged, $25 \%$ reported that they felt they were not good at it, thus confirming weak performance beliefs regarding cognitive disengagement (Murray 2013). A weak or negative performance belief in cognitive disengagement influences writing, according to participants, by acting as a barrier to engaging with writing. 


\section{Discussion}

Table 2 highlights that most programmes address the performance and process beliefs of individual academics. This means that programmes enhance academics' beliefs that they know what they need to do in terms of the nature and style of academic writing (Baldwin and Chandler 2002; Lillis, Magyar and Robinson-Pant 2010) or the writing process (MacLeod, Steckley and Murray 2012). This was achieved by providing mentoring, coaching and workshops using experts such as journal editors and reviewers (Jackson 2009; Lillis, Magyar and Robinson-Pant 2010; Dwyer et al. 2015) and/or mentoring and coaching by peers (Jackson 2009; Murray and Thow 2014). This happened either in the workplace individually or in group settings, or at writing retreats in various formats. Writing retreats commonly had structured programmes of writing, which have been found previously to be most effective in enhancing research output (McGrail, Rickard and Jones 2006).

The performance belief that the academic was able to perform the required behaviours was achieved in most studies by means of successful engagement with writing (Murray 2013), review and monitoring of writing (Baldwin and Chandler 2002), skills development (Lillis, Magyar and Robinson-Pant 2010) and minimizing anxiety about writing (Dwyer et al. 2015).

\section{***INSERT TABLE $2 . * * *$}

Nearly all studies showed enhanced prospect beliefs, in terms of strengthening beliefs that the desired outcome of writing was achievable. This generally occurred through the completion of manuscripts in most of the programmes. However, one of the beliefs least addressed is the academic's profit beliefs, the belief that the achievement of goals leads to personal gain. This perception of gain can either take the form of personal gratification, such as pride or satisfaction in achievements, or status, such as financial or career gains. Weak or low profit beliefs call into question the academic's motivation and commitment to writing, if they perceive that nothing is gained by completing publications. Profit beliefs were addressed directly in only two programmes (Baldwin and Chandler 2002; Murray and Thow 2014). Both the coaching in Baldwin and Chandler's (2002) programme and the writing meeting in Murray and Thow (2014) emphasise the importance of making sense of the role of writing for the academic and facilitating a decisional balance that favours writing as opposed to not-writing. Through review and monitoring of goals both programmes explicitly celebrate achievements. The other aspect of profit belief in research output leading to gain in relation to career or academic progression appears to be assumed in all these studies. This may be because participants were selfselected and therefore held sufficient beliefs that writing would lead to career progression or maintenance. While this seems a strong motivator for an academic to engage and persist with writing, 
it was not addressed nor evaluated in any of the studies. Yet, it is important, since Van Egeren (2000) suggests that a negative profit belief can lead to emotions associated with loss of an anticipated outcome, such as grief or bitterness. This can occur, for example, when completion of a doctoral degree or increase in publications does not lead to career progression or promotion. This is an area that requires further investigation as a potential factor in academics' writing behaviours.

Table 3 shows that nearly all programmes addressed the importance of a positive and supportive micro- and mesosystem. This was achieved through structured and unstructured peer support (Jackson 2009; Murray and Thow 2014) or mentoring or coaching (Baldwin and Chandler 2002; Lillis, Magyar and Robinson-Pant 2010). Lillis, Magyar and Robinson-Pant is an interesting example here, as the positive microsystem was created by journal editors and reviewers, who acted as mentors, normally considered part of the macrosystem. The microsystem in most other studies included academic peers (e.g. MacLeod, Steckley and Murray 2012) or colleagues (Dwyer et al. 2015). This raises the question of what kind of microsystem or mesosystem is most beneficial to academics as, apart from Dwyer et al. (2015), no study addressed the immediate work micro- or mesosystem of the academic. Is a positive microsystem sufficient if it is derived from peers at other institutions? Further investigation is required, although this is alluded to in, for example, Murray (2013), where participants described the contrast between the academic's immediate microsystem and the microsystem developed at writing retreats.

\section{***INSERT TABLE $3 . * * *$}

The exosystem was not directly addressed in many writing programmes. The support of the Dean or management in providing a writing support coach was perceived as supportive and enabling element of the programme (Dwyer et al. 2015; Jackson 2009). The support from the exosystem was also reflected in the concept of organisational containment provided at Structured Writing Retreats (MacLeod, Steckley and Murray 2012) by clarifying writing as task primacy. While the exosystem is not changed, the perception of a negative exosystem is addressed in the writing meeting (Murray and Thow 2014).

The macrosystem is addressed in only two studies (Lillis, Magyar and Robinson-Pant 2010; Dwyer et al. 2015) by including journal editors and reviewers. As stated previously, it was interesting to note that the macrosystem evolved to become part of the microsystem in these studies. 


\section{Recommendations for practice}

To take this model and implement the implications of this analysis here are some recommendations for practice:

- Writing interventions should have a theoretical or conceptual underpinning to further our understanding of writing practices and cultures.

- The transactional and systems model should be used to identify individual and institutional barriers to writing and plan writing interventions to support positive changes in writing practices and cultures.

- Interventions that encourage a review of the academic's decisional balance regarding writing, such as the Writing Meeting and Writing Coaching should be used to address individual barriers to writing.

- To ensure sustained changes in writing practices and cultures, organisations must support academics to develop stronger control beliefs regarding writing; while creating supportive environments for these beliefs to develop.

- More attention should be given to perceptions of profit to be gained from academic writing.

- To change writing practices, more attention should be given to macrosystems in which academics are embedded.

\section{Conclusion}

All the studies reviewed reported positive outcomes in terms of qualitative findings, ranging from a sense of satisfaction (Lillis, Magyar and Robinson-Pant 2010) to developing an identity as a writer (Murray 2013). Where quantitative findings are presented, programmes are generally effective in getting manuscripts ready for submission to a journal. However, while all these programmes have something to offer in terms of facilitating research output, none of them address all aspects of the transactional and/or systems approach in particular in addressing profit beliefs and macrosystems. This may explain why their impact and the sustainability of their impact are generally limited. In the absence of evidence regarding the scale of effect and sustained impact, we suggest that these interventions may, therefore, have limited short-term impact, and are unlikely to lead to sustained change in writing cultures and practices in academia. For programmes to make sustained differences to the writing practices and culture of academics, all domains within the transactional and systems approach must be addressed. For example, offering writing workshops and retreats will not be beneficial unless the exosystem (HEI) embeds the importance of writing in strategy and policy documents. Staff need the opportunity to reframe or rebalance workloads and responsibilities to allow 
regular prioritisation of writing. In addition, writing interventions and programmes should not be seen as a quick fix but should be provided on an ongoing basis to support academic staff to create, edit and submit research output. 


\section{References}

Baldwin, C., and G.E. Chandler. 2002. "Improving faculty publication output: the role of a writing coach." Journal of Professional Nursing 18(1): 8-15.

Blanchard, K., P. Zigarmi, and D. Zigarmi. 1985. Leadership and the one minute manager. New York: Morrow.

Bronfenbrenner, U. 1979. The ecology of human development. Cambridge, MA: Harvard University Press.

Dickson-Swift, V., E.L. James, S. Kippen, L. Talbot, G. Verrinder, and B. Ward. 2009. “A nonresidential alternative to off campus writers' retreats for academics." Journal of Further and Higher Education 33(3): 229-239.

Dwyer, T., D. Friel, M. McAllister, K.R. Searl, and D. Rossi. 2015. "The write stuff: A proactive approach to increasing academics' writing skills and outcomes." Nurse education in practice 15(4): 321-326.

Evered, R.D., and J.C. Selman. 1989. "Coaching and the art of management." Organizational Dynamics 18(2): 16-32.

Galipeau, J., D. Moher, C. Campbell, P. Hendry, D.W. Cameron, A. Palepu, and P.C. Hébert. 2015. "A systematic review highlights a knowledge gap regarding the effectiveness of health-related training programs in journalology." Journal of Clinical Epidemiology 68(3): 257-265.

Grant, B., and S. Knowles. 2000. "Flights of imagination: Academic women be(com)ing writers." International Journal for Academic Development 5: 6-19. doi: $10.1080 / 136014400410060$

Herman, J., M. Abate, and T.E. Walker. 2013. "Faculty writing retreat: fostering writing productivity, collaboration, and community-building through an interdisciplinary, multi-day program." International Journal of University Teaching and Faculty Development 4(4): 193.

Hicks, D. 2012. "Performance-based university research funding systems." Research Policy 41(2): 251-261. 
House, J. 1981. Work stress and social support. Reading, MA: Addison-Wesley.

Jackson, D. 2009. "Mentored residential writing retreats: A leadership strategy to develop skills and generate outcomes in writing for publication." Nurse Education Today 29(1): 9-15.

Johnston, J., S. Wilson., E. Rix, and S.W. Pit. 2014. "Publish or perish: strategies to help rural early career researchers increase publication output." Rural and Remote Health 14(2870).

Kempenaar, L.E., and R. Murray. 2016. "Writing by academics: a transactional and systems approach to academic writing behaviours." Higher Education Research and Development, 1-11.

Lazarus, R. S., and S. Folkman. 1984. Stress, appraisal, and coping. New York, NY: Springer Publishing.

Lillis, T., and M. Scott. 2007. "Defining academic literacies research: Issues of epistemology, ideology and strategy." Journal of applied linguistics 4(1): 5-32.

Lillis, T., A. Magyar, and A. Robinson-Pant. 2010. “An international journal's attempts to address inequalities in academic publishing: developing a writing for publication programme." Compare 40(6): 781-800.

MacLeod, I., L. Steckley, and R. Murray. 2012. "Time is not enough: promoting strategic engagement with writing for publication." Studies in Higher Education 37(6): 641-654.

Mayrath, M. C. 2008. "Attributions of productive authors in educational psychology journals." Educational Psychology Review 20: 41-56. doi: 10.1007/s10648-007-9059-y

McGrail, M. R., C.M. Rickard, and R. Jones. 2006. "Publish or perish: a systematic review of interventions to increase academic publication rates." Higher Education Research and Development 25(1): 19-35.

Menzies-Lyth, I. 1988. Containing anxiety in institutions: selected essays. Volume one. London: Free Association Books.

Miller, W.R., \& S. Rollnick. 2002. Motivational interviewing: Preparing people for change (2nd ed.). London: Guildford Press. 
Moore, S. 2003. "Writers' retreats for academics: exploring and increasing the motivation to write." Journal of Further and Higher Education 27: 333-342. doi:

$10.1080 / 0309877032000098734$

Murray, R. 2013. “'It's not a hobby': reconceptualizing the place of writing in academic work." Higher Education 66(1): 79-91.

Murray, R., and M. Newton. 2009. "Writing retreat as structured intervention: margin or mainstream?" Higher education research and development 28(5): 541-553.

Murray, R., and M. Thow. 2014. "Peer-formativity: a framework for academic writing." Higher Education Research and Development 33(6): 1166-1179. http://www.tandfonline.com/doi/abs/10.1080/07294360.2014.911252

Nielsen, M.W. 2015. "Limits to meritocracy? Gender in academic recruitment and promotion processes." Science and Public Policy p.scv: 052.

Paliadelis, P., V. Parker, G. Parmenter, and M. Maple. 2015. “"Right' for publication: strategies for supporting novice writers across health and medical disciplines." Australian Health Review 39(2): 165-168.

Pololi, L., S. Knight, and K. Dunn. 2004. Facilitating scholarly writing in academic medicine. Journal of General Internal Medicine 19(1): 64-68.

Reidpath, D. D., and P. Allotey. 2010. "Can national research assessment exercises be used locally to inform research strategy development? The description of a methodological approach to the UK RAE 2008 results with a focus on one institution." Higher Education, 59: 785-797. doi: $10.1007 / \mathrm{s} 10734-009-9280-3$

Spears, L. C. 2004. "Practicing servant-leadership". Leader to leader 34: 7-11.

Van Egeren, L. 2000. "Stress and coping and behavioral organization." Psychosomatic Medicine 62: 451-460.

Wenger, E. 1998. Communities of practice: learning, meaning and identity. Cambridge: Cambridge University Press. 
Wenger, E., McDermott, R. A., and W. Snyder. 2002. Cultivating communities of practice: A guide to managing knowledge. Boston: Harvard Business Press. 
Table 1. Overview of writing programmes

\begin{tabular}{|c|c|c|c|c|c|c|}
\hline $\begin{array}{l}\text { Authors } \\
\text { (year) }\end{array}$ & Framework & Programme & Duration & Frequency & $\begin{array}{l}\text { Participants } \\
\text { Design }\end{array}$ & Outcome \\
\hline $\begin{array}{l}\text { Baldwin } \\
\text { and } \\
\text { Chandler } \\
(2002)\end{array}$ & $\begin{array}{l}\text { Situational } \\
\text { leadership }\end{array}$ & $\begin{array}{l}\text { Writing coach } \\
\text { Evered and } \\
\text { Selman (1989) } \\
\text { House (1981) } \\
\text { Support to } \\
\text { create, write, } \\
\text { edit and submit } \\
\text { manuscripts }\end{array}$ & 2.5 years & $\begin{array}{l}\text { Average } \\
15 \text { hours } \\
\text { per month } \\
\text { per person } \\
\text { (range 3.7- } \\
33.1 \text { ) }\end{array}$ & $\begin{array}{l}16 \text { out of } 26 \\
\text { participants } \\
\text { Research } \\
\text { output }\end{array}$ & $\begin{array}{l}21 \text { manuscripts } \\
\text { submitted } \\
15 \text { published } \\
\text { Increase from } 13 \text { to } \\
20 \text { publications } \\
\text { Change from 'high } \\
\text { priority and low } \\
\text { follow-through } \\
\text { behavior' to 'inner- } \\
\text { directed and } \\
\text { institutionally } \\
\text { supported activity' }\end{array}$ \\
\hline $\begin{array}{l}\text { Jackson } \\
(2009)\end{array}$ & $\begin{array}{l}\text { Servant } \\
\text { leadership }\end{array}$ & $\begin{array}{l}\text { Residential } \\
\text { writing retreat } \\
\text { Typing pool } \\
\text { writing } \\
\text { Servant leader } \\
\text { mentors } \\
\text { Peer-learning } \\
\text { partnerships }\end{array}$ & 3 days & $\begin{array}{l}3 \text { retreats } \\
\text { over } 3 \\
\text { years }\end{array}$ & $\begin{array}{l}39 \\
\text { participants }\end{array}$ & $\begin{array}{l}37 \text { manuscripts } \\
\text { submitted } \\
17 \text { accepted for } \\
\text { publication } \\
1 \text { revision } \\
19 \text { under review } \\
\text { Feeling valued by } \\
\text { peers, mentors, and } \\
\text { by their institution }\end{array}$ \\
\hline $\begin{array}{l}\text { Lillis, } \\
\text { Magyar } \\
\text { and } \\
\text { Robinson- } \\
\text { Pant } \\
(2010)\end{array}$ & $\begin{array}{l}\text { Academic } \\
\text { literacies } \\
\text { framework }\end{array}$ & $\begin{array}{l}\text { Increase access } \\
\text { of resources to } \\
\text { publish in an } \\
\text { Anglophone } \\
\text { centred } \\
\text { journal: } \\
\text { Mentorship } \\
\text { from journal } \\
\text { editors and } \\
\text { reviewers } \\
\text { (Compare) }\end{array}$ & $\begin{array}{l}\text { One-day } \\
\text { workshop, } \\
\text { 4-month } \\
\text { mentorship } \\
\text { to submit } \\
\text { article to } \\
\text { journal }\end{array}$ & $\begin{array}{l}\text { As and } \\
\text { when }\end{array}$ & $\begin{array}{l}55 \\
\text { participants } \\
\text { Submissions } \\
\text { to Compare }\end{array}$ & $\begin{array}{l}30 \text { articles submitted } \\
\text { ( } 29 \text { to Compare) } \\
4 \text { rejected } \\
10 \text { were accepted } \\
15 \text { requiring } \\
\text { resubmission } \\
\text { Sense of satisfaction }\end{array}$ \\
\hline $\begin{array}{l}\text { MacLeod, } \\
\text { Steckley } \\
\text { and } \\
\text { Murray } \\
(2012)\end{array}$ & Containment & $\begin{array}{l}\text { Residential } \\
\text { structured } \\
\text { writing retreat } \\
\text { Typing pool } \\
\text { Secluded } \\
\text { location, peer } \\
\text { discussion and } \\
\text { goal setting, } \\
\text { shared time and } \\
\text { space } \\
\text { Leadership to } \\
\text { adhere to fixed } \\
\text { writing slots, } \\
\text { prioritise } \\
\text { writing }\end{array}$ & 2 days & $\begin{array}{l}\text { Attendance } \\
\text { at } \geq 1 \\
\text { retreat }\end{array}$ & $\begin{array}{l}27 \\
\text { participants } \\
\text { Semi- } \\
\text { structured } \\
\text { interviews } \\
\text { Framework } \\
\text { analysis } \\
\text { using } \\
\text { concept of } \\
\text { containment }\end{array}$ & $\begin{array}{l}\text { Containment } \\
\text { provided by retreat } \\
\text { structure and } \\
\text { leadership: } \\
\text { emotional } \\
\text { epistemological } \\
\text { organisational }\end{array}$ \\
\hline
\end{tabular}




\begin{tabular}{|c|c|c|c|c|c|c|}
\hline (year) & & & & & Design & \\
\hline $\begin{array}{l}\text { Murray } \\
(2013)\end{array}$ & Engagement & $\begin{array}{ll}\text { Residential } \\
\text { structured writing } \\
\text { retreat } \\
\text { - } \quad \text { Typing pool } \\
\text { - } \quad \text { Secluded } \\
\text { location, peer } \\
\text { discussion and } \\
\text { goal setting, } \\
\text { shared time } \\
\text { and space } \\
\text { Engagement } \\
\text { with writing } \\
\text { through } \\
\text { disengagement } \\
\text { from other } \\
\text { roles and } \\
\text { responsibilities }\end{array}$ & 2 days & 1 & $\begin{array}{l}12 \\
\text { participants } \\
\text { Questionnaire }\end{array}$ & $\begin{array}{l}\text { Engagement through } \\
\text { disengagement } \\
\text { - } \quad \text { Cognitive } \\
\text { - } \quad \text { Social } \\
\text { - } \quad \text { Physical }\end{array}$ \\
\hline $\begin{array}{l}\text { Murray } \\
\text { and } \\
\text { Thow } \\
\text { (2014) }\end{array}$ & $\begin{array}{l}\text { Stages of } \\
\text { change }\end{array}$ & $\begin{array}{l}\text { Writing meeting } \\
\text { with peer } \\
\text { - } \quad \text { pros and cons } \\
\text { of writing } \\
\text { - } \quad \text { identify } \\
\text { barriers to } \\
\text { both starting } \\
\text { and } \\
\text { maintaining } \\
\text { writing } \\
\text { practices } \\
\text { goal setting } \\
\text { - actions to } \\
\text { achieve these } \\
\text { goals } \\
\text { time for } \\
\text { review the } \\
\text { goals set }\end{array}$ & 8 weeks & 4 meetings & $\begin{array}{l}14 \\
\text { participants } \\
\text { Framework } \\
\text { analysis of } \\
\text { meeting and } \\
\text { interview } \\
\text { transcripts } \\
3 \text { core } \\
\text { constructs }\end{array}$ & 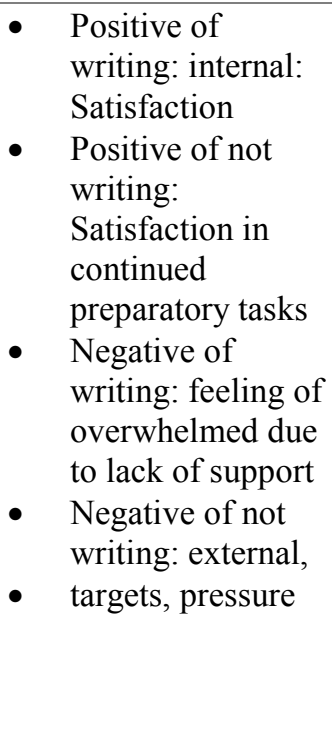 \\
\hline $\begin{array}{l}\text { Dwyer } \\
\text { et al. } \\
(2015)\end{array}$ & $\begin{array}{l}\text { Communities } \\
\text { of practice }\end{array}$ & $\begin{array}{l}\text { Residential writing } \\
\text { retreat } \\
\text { group and solitary } \\
\text { writing and } \\
\text { activities } \\
\text { Mentorship from } \\
\text { journal } \\
\text { editors/reviewers } \\
\text { Structured writing } \\
\text { skills workshops } \\
\text { prior to and during } \\
\text { the retreat } \\
\text { relaxation } \\
\text { team building } \\
\text { Aim: submit one } \\
\text { article to SCOPUS } \\
\text { journal }\end{array}$ & $\begin{array}{l}2 \text { days, } \\
\text { followed } \\
\text { by } 3 \mathrm{hr} \\
\text { writing } \\
\text { sessions }\end{array}$ & Weekly & $\begin{array}{l}\text { Questionnaire } \\
\text { Focus group }\end{array}$ & $\begin{array}{l}\text { Contribution of } \\
\text { facilitators positive } \\
\text { - } \quad \text { Timely feedback } \\
\text { - } \quad \text { Person centred, } \\
\quad \text { accessible } \\
\text { - } \quad \text { Knowledgeable } \\
\text { - } \quad \text { Reframing } \\
\quad \text { writing } \\
\text { Supportive peer group } \\
\text { - Reciprocal } \\
\text { Achievement of } \\
\text { personal goals ( } 77 \%) \\
\text { Desire for more time } \\
\text { to write }\end{array}$ \\
\hline
\end{tabular}

Table 2. Writing programmes within the transactional approach 


\begin{tabular}{|c|c|c|c|c|c|}
\hline $\begin{array}{l}\text { Authors } \\
\text { (year) }\end{array}$ & $\begin{array}{l}\text { Domain } \\
\text { Framework }\end{array}$ & $\begin{array}{l}\text { Performance } \\
\text { belief }^{1}\end{array}$ & Process belief $^{2}$ & $\begin{array}{l}\text { Prospect } \\
\text { belief }^{3}\end{array}$ & Profit belief $^{4}$ \\
\hline $\begin{array}{l}\text { Baldwin and } \\
\text { Chandler } \\
(2002)\end{array}$ & $\begin{array}{l}\text { Situational } \\
\text { leadership }\end{array}$ & $\begin{array}{l}\text { Review and } \\
\text { monitoring }\end{array}$ & Writing coach & Writing coach & $\begin{array}{l}\text { Celebration of } \\
\text { achievement with } \\
\text { coach }\end{array}$ \\
\hline $\begin{array}{l}\text { Jackson } \\
(2009)\end{array}$ & $\begin{array}{l}\text { Servant } \\
\text { leadership }\end{array}$ & Writing time & Writing support & $\begin{array}{l}\text { Deadlines and } \\
\text { writing goals }\end{array}$ & $\mathrm{x}$ \\
\hline $\begin{array}{l}\text { Lillis, Magyar } \\
\text { and } \\
\text { Robinson- } \\
\text { Pant (2010) }\end{array}$ & $\begin{array}{l}\text { Academic } \\
\text { literacies } \\
\text { framework }\end{array}$ & $\begin{array}{l}\text { Writing, } \\
\text { rewriting } \\
\text { abstract } \\
\text { Hands on } \\
\text { mentors }\end{array}$ & $\begin{array}{l}\text { Clarifying the } \\
\text { style and nature } \\
\text { of writing }\end{array}$ & $\begin{array}{l}\text { Accepted } \\
\text { manuscripts }\end{array}$ & $\mathrm{x}$ \\
\hline $\begin{array}{l}\text { MacLeod, } \\
\text { Steckley and } \\
\text { Murray } \\
(2012)\end{array}$ & Containment & $\begin{array}{l}\text { Emotional } \\
\text { containment }\end{array}$ & Task primacy & Task primacy & $\begin{array}{l}\text { Epistemological } \\
\text { containment }\end{array}$ \\
\hline $\begin{array}{l}\text { Murray } \\
(2013)\end{array}$ & Engagement & $\begin{array}{l}\text { Cognitive, } \\
\text { emotional and } \\
\text { physical } \\
\text { engagement }\end{array}$ & $\begin{array}{l}\text { Cognitive, } \\
\text { emotional and } \\
\text { physical } \\
\text { engagement }\end{array}$ & $\begin{array}{l}\text { Research } \\
\text { output }\end{array}$ & $\mathrm{x}$ \\
\hline $\begin{array}{l}\text { Murray and } \\
\text { Thow (2014) }\end{array}$ & $\begin{array}{l}\text { Stages of } \\
\text { change }\end{array}$ & $\begin{array}{l}\text { Decisional } \\
\text { balance }\end{array}$ & Action planning & $\begin{array}{l}\text { Goal setting } \\
\text { and review }\end{array}$ & $\begin{array}{l}\text { Alignment with } \\
\text { institutional values }\end{array}$ \\
\hline $\begin{array}{l}\text { Dwyer et al. } \\
(2015)\end{array}$ & $\begin{array}{l}\text { Communities } \\
\text { of practice }\end{array}$ & $\begin{array}{l}\text { Minimize } \\
\text { anxiety about } \\
\text { writing }\end{array}$ & $\begin{array}{l}\text { Skill } \\
\text { development }\end{array}$ & $\mathrm{X}$ & $\mathrm{x}$ \\
\hline
\end{tabular}

${ }^{1}$ Performance belief: The academic's belief that they personally can perform the behaviours required to produce writing

${ }^{2}$ Process belief: The academics' belief that they are able to actively change the environment to produce writing.

${ }^{3}$ Prospect belief: The academics' belief that the desired outcome of the writing are achievable ${ }^{4}$ Profit belief: The academics' belief that achievement of these writing goals, i.e. publications, will benefit them personally in some way 
Table 3. Writing programmes within systems approach

\begin{tabular}{|c|c|c|c|c|c|}
\hline $\begin{array}{l}\text { Authors } \\
\text { (year) }\end{array}$ & $\begin{array}{l}\text { Domain } \\
\text { Framework }\end{array}$ & Microsystem $^{1}$ & Mesosystem $^{2}$ & Exosystem $^{3}$ & Macrosystem $^{4}$ \\
\hline $\begin{array}{l}\text { Baldwin and } \\
\text { Chandler } \\
(2002)\end{array}$ & $\begin{array}{l}\text { Situational } \\
\text { leadership }\end{array}$ & Coach & $\begin{array}{l}\text { Situational } \\
\text { leadership and } \\
\text { coaching }\end{array}$ & $\begin{array}{l}\text { Supportive Dean } \\
\text { of Faculty: time }\end{array}$ & $\mathrm{x}$ \\
\hline $\begin{array}{l}\text { Jackson } \\
(2009)\end{array}$ & $\begin{array}{l}\text { Servant } \\
\text { leadership }\end{array}$ & $\begin{array}{l}\text { Mentors } \\
\text { Peer learning } \\
\text { partnerships }\end{array}$ & $\begin{array}{l}\text { Servant } \\
\text { leadership }\end{array}$ & $\begin{array}{l}\text { Time and money } \\
\text { to attend }\end{array}$ & $\mathrm{x}$ \\
\hline $\begin{array}{l}\text { Lillis, } \\
\text { Magyar and } \\
\text { Robinson- } \\
\text { Pant (2010) }\end{array}$ & $\begin{array}{l}\text { Academic } \\
\text { literacies } \\
\text { framework }\end{array}$ & $\begin{array}{l}\text { Editors evolve } \\
\text { to a } \\
\text { microsystem } \\
\text { rather than } \\
\text { macro only }\end{array}$ & $\mathrm{x}$ & $\mathrm{x}$ & $\begin{array}{l}\text { Cultural aspects of } \\
\text { the journal }\end{array}$ \\
\hline $\begin{array}{l}\text { MacLeod, } \\
\text { Steckley and } \\
\text { Murray } \\
(2012)\end{array}$ & Containment & $\mathrm{x}$ & Task primacy & $\begin{array}{l}\text { Organisational } \\
\text { containment } \\
\text { Task primacy }\end{array}$ & $\mathrm{x}$ \\
\hline $\begin{array}{l}\text { Murray } \\
(2013)\end{array}$ & Engagement & $\begin{array}{l}\text { Controlled } \\
\text { environment }\end{array}$ & $\begin{array}{l}\text { Like minded } \\
\text { participants }\end{array}$ & $\begin{array}{l}\text { Disengagement } \\
\text { from unhelpful } \\
\text { system }\end{array}$ & $\mathrm{x}$ \\
\hline $\begin{array}{l}\text { Murray and } \\
\text { Thow (2014) }\end{array}$ & $\begin{array}{l}\text { Stages of } \\
\text { change }\end{array}$ & Writing meeting & Peer facilitation & $\begin{array}{l}\text { Alignment with } \\
\text { institutional } \\
\text { values }\end{array}$ & $\mathrm{x}$ \\
\hline $\begin{array}{l}\text { Dwyer et al. } \\
(2015)\end{array}$ & $\begin{array}{l}\text { Communities } \\
\text { of practice }\end{array}$ & $\begin{array}{l}\text { Shared space, } \\
\text { time and writing } \\
\text { Secluded } \\
\text { location }\end{array}$ & $\begin{array}{l}\text { Group activities } \\
\text { Development of } \\
\text { reciprocal } \\
\text { 'obligation' for } \\
\text { support }\end{array}$ & $\mathrm{x}$ & $\begin{array}{l}\text { Feedback from } \\
\text { journal } \\
\text { reviewers/editors }\end{array}$ \\
\hline
\end{tabular}

${ }^{1}$ Microsystem: The relationships between the academic and their immediate work environment

${ }^{2}$ Mesosystem: The relationships between the people in the microsystem

${ }^{3}$ Exosystem: The Higher Education institution

${ }^{4}$ Macrosystem: Society, government structures and academic cultures 
Table 1. Overview of writing programmes

\begin{tabular}{|c|c|c|c|c|c|c|}
\hline $\begin{array}{l}\text { Authors } \\
\text { (year) }\end{array}$ & Framework & Programme & Duration & Frequency & $\begin{array}{l}\text { Participants } \\
\text { Design }\end{array}$ & Outcome \\
\hline $\begin{array}{l}\text { Baldwin } \\
\text { and } \\
\text { Chandler } \\
(2002)\end{array}$ & $\begin{array}{l}\text { Situational } \\
\text { leadership }\end{array}$ & $\begin{array}{l}\text { Writing coach } \\
\text { Evered and } \\
\text { Selman (1989) } \\
\text { House (1981) } \\
\text { Support to } \\
\text { create, write, } \\
\text { edit and submit } \\
\text { manuscripts }\end{array}$ & 2.5 years & $\begin{array}{l}\text { Average } \\
15 \text { hours } \\
\text { per month } \\
\text { per person } \\
\text { (range 3.7- } \\
33.1 \text { ) }\end{array}$ & $\begin{array}{l}16 \text { out of } 26 \\
\text { participants } \\
\text { Research } \\
\text { output }\end{array}$ & $\begin{array}{l}21 \text { manuscripts } \\
\text { submitted } \\
15 \text { published } \\
\text { Increase from } 13 \text { to } \\
20 \text { publications } \\
\text { Change from 'high } \\
\text { priority and low } \\
\text { follow-through } \\
\text { behavior' to 'inner- } \\
\text { directed and } \\
\text { institutionally } \\
\text { supported activity' }\end{array}$ \\
\hline $\begin{array}{l}\text { Jackson } \\
(2009)\end{array}$ & $\begin{array}{l}\text { Servant } \\
\text { leadership }\end{array}$ & $\begin{array}{l}\text { Residential } \\
\text { writing retreat } \\
\text { Typing pool } \\
\text { writing } \\
\text { Servant leader } \\
\text { mentors } \\
\text { Peer-learning } \\
\text { partnerships }\end{array}$ & 3 days & $\begin{array}{l}3 \text { retreats } \\
\text { over } 3 \\
\text { years }\end{array}$ & $\begin{array}{l}39 \\
\text { participants }\end{array}$ & $\begin{array}{l}37 \text { manuscripts } \\
\text { submitted } \\
17 \text { accepted for } \\
\text { publication } \\
1 \text { revision } \\
19 \text { under review } \\
\text { Feeling valued by } \\
\text { peers, mentors, and } \\
\text { by their institution }\end{array}$ \\
\hline $\begin{array}{l}\text { Lillis, } \\
\text { Magyar } \\
\text { and } \\
\text { Robinson- } \\
\text { Pant } \\
(2010)\end{array}$ & $\begin{array}{l}\text { Academic } \\
\text { literacies } \\
\text { framework }\end{array}$ & $\begin{array}{l}\text { Increase access } \\
\text { of resources to } \\
\text { publish in an } \\
\text { Anglophone } \\
\text { centred } \\
\text { journal: } \\
\text { Mentorship } \\
\text { from journal } \\
\text { editors and } \\
\text { reviewers } \\
\text { (Compare) }\end{array}$ & $\begin{array}{l}\text { One-day } \\
\text { workshop, } \\
\text { 4-month } \\
\text { mentorship } \\
\text { to submit } \\
\text { article to } \\
\text { journal }\end{array}$ & $\begin{array}{l}\text { As and } \\
\text { when }\end{array}$ & $\begin{array}{l}55 \\
\text { participants } \\
\text { Submissions } \\
\text { to Compare }\end{array}$ & $\begin{array}{l}30 \text { articles submitted } \\
\text { ( } 29 \text { to Compare) } \\
4 \text { rejected } \\
10 \text { were accepted } \\
15 \text { requiring } \\
\text { resubmission } \\
\text { Sense of satisfaction }\end{array}$ \\
\hline $\begin{array}{l}\text { MacLeod, } \\
\text { Steckley } \\
\text { and } \\
\text { Murray } \\
(2012)\end{array}$ & Containment & $\begin{array}{l}\text { Residential } \\
\text { structured } \\
\text { writing retreat } \\
\text { Typing pool } \\
\text { Secluded } \\
\text { location, peer } \\
\text { discussion and } \\
\text { goal setting, } \\
\text { shared time and } \\
\text { space } \\
\text { Leadership to } \\
\text { adhere to fixed } \\
\text { writing slots, } \\
\text { prioritise } \\
\text { writing }\end{array}$ & 2 days & $\begin{array}{l}\text { Attendance } \\
\text { at } \geq 1 \\
\text { retreat }\end{array}$ & $\begin{array}{l}27 \\
\text { participants } \\
\text { Semi- } \\
\text { structured } \\
\text { interviews } \\
\text { Framework } \\
\text { analysis } \\
\text { using } \\
\text { concept of } \\
\text { containment }\end{array}$ & $\begin{array}{l}\text { Containment } \\
\text { provided by retreat } \\
\text { structure and } \\
\text { leadership: } \\
\text { emotional } \\
\text { epistemological } \\
\text { organisational }\end{array}$ \\
\hline
\end{tabular}




\begin{tabular}{|c|c|c|c|c|c|c|}
\hline (year) & & & & & Design & \\
\hline $\begin{array}{l}\text { Murray } \\
(2013)\end{array}$ & Engagement & $\begin{array}{l}\text { Residential } \\
\text { structured writing } \\
\text { retreat } \\
\text { - Typing pool } \\
\text { - } \quad \text { Secluded } \\
\text { location, peer } \\
\text { discussion and } \\
\text { goal setting, } \\
\text { shared time } \\
\text { and space } \\
\text { Engagement } \\
\text { with writing } \\
\text { through } \\
\text { disengagement } \\
\text { from other } \\
\text { roles and } \\
\text { responsibilities }\end{array}$ & 2 days & 1 & $\begin{array}{l}12 \\
\text { participants } \\
\text { Questionnaire }\end{array}$ & $\begin{array}{l}\text { Engagement through } \\
\text { disengagement } \\
\text { - } \quad \text { Cognitive } \\
\text { - } \quad \text { Social } \\
\text { - } \quad \text { Physical }\end{array}$ \\
\hline $\begin{array}{l}\text { Murray } \\
\text { and } \\
\text { Thow } \\
\text { (2014) }\end{array}$ & $\begin{array}{l}\text { Stages of } \\
\text { change }\end{array}$ & $\begin{array}{l}\text { Writing meeting } \\
\text { with peer } \\
\text { - } \quad \text { pros and cons } \\
\text { of writing } \\
\text { - } \quad \text { identify } \\
\text { barriers to } \\
\text { both starting } \\
\text { and } \\
\text { maintaining } \\
\text { writing } \\
\text { practices } \\
\text { goal setting } \\
\text { - actions to } \\
\text { achieve these } \\
\text { goals } \\
\text { time for } \\
\text { review the } \\
\text { goals set }\end{array}$ & 8 weeks & 4 meetings & $\begin{array}{l}14 \\
\text { participants } \\
\text { Framework } \\
\text { analysis of } \\
\text { meeting and } \\
\text { interview } \\
\text { transcripts } \\
3 \text { core } \\
\text { constructs }\end{array}$ & $\begin{array}{l}\text { Positive of } \\
\text { writing: internal: } \\
\text { Satisfaction } \\
\text { Positive of not } \\
\text { writing: } \\
\text { Satisfaction in } \\
\text { continued } \\
\text { preparatory tasks } \\
\text { Negative of } \\
\text { writing: feeling of } \\
\text { overwhelmed due } \\
\text { to lack of support } \\
\text { Negative of not } \\
\text { writing: external, } \\
\text { targets, pressure }\end{array}$ \\
\hline $\begin{array}{l}\text { Dwyer } \\
\text { et al. } \\
(2015)\end{array}$ & $\begin{array}{l}\text { Communities } \\
\text { of practice }\end{array}$ & $\begin{array}{l}\text { Residential writing } \\
\text { retreat } \\
\text { group and solitary } \\
\text { writing and } \\
\text { activities } \\
\text { Mentorship from } \\
\text { journal } \\
\text { editors/reviewers } \\
\text { Structured writing } \\
\text { skills workshops } \\
\text { prior to and during } \\
\text { the retreat } \\
\text { relaxation } \\
\text { team building } \\
\text { Aim: submit one } \\
\text { article to SCOPUS } \\
\text { journal }\end{array}$ & $\begin{array}{l}2 \text { days, } \\
\text { followed } \\
\text { by } 3 \mathrm{hr} \\
\text { writing } \\
\text { sessions }\end{array}$ & Weekly & $\begin{array}{l}\text { Questionnaire } \\
\text { Focus group }\end{array}$ & $\begin{array}{l}\text { Contribution of } \\
\text { facilitators positive } \\
\text { - } \quad \text { Timely feedback } \\
\text { - } \quad \text { Person centred, } \\
\text { accessible } \\
\text { - } \quad \text { Knowledgeable } \\
\text { - } \quad \text { Reframing } \\
\quad \text { writing } \\
\text { Supportive peer group } \\
\text { - } \quad \text { Reciprocal } \\
\text { Achievement of } \\
\text { personal goals ( } 77 \%) \\
\text { Desire for more time } \\
\text { to write }\end{array}$ \\
\hline
\end{tabular}


Table 2. Writing programmes within the transactional approach

\begin{tabular}{|c|c|c|c|c|c|}
\hline $\begin{array}{l}\text { Authors } \\
\text { (year) }\end{array}$ & $\begin{array}{l}\text { Domain } \\
\text { Framework }\end{array}$ & $\begin{array}{l}\text { Performance } \\
\text { belief }^{1}\end{array}$ & Process belief $^{2}$ & $\begin{array}{l}\text { Prospect } \\
\text { belief }^{3}\end{array}$ & Profit belief $^{4}$ \\
\hline $\begin{array}{l}\text { Baldwin and } \\
\text { Chandler } \\
(2002)\end{array}$ & $\begin{array}{l}\text { Situational } \\
\text { leadership }\end{array}$ & $\begin{array}{l}\text { Review and } \\
\text { monitoring }\end{array}$ & Writing coach & Writing coach & $\begin{array}{l}\text { Celebration of } \\
\text { achievement with } \\
\text { coach }\end{array}$ \\
\hline $\begin{array}{l}\text { Jackson } \\
(2009)\end{array}$ & $\begin{array}{l}\text { Servant } \\
\text { leadership }\end{array}$ & Writing time & Writing support & $\begin{array}{l}\text { Deadlines and } \\
\text { writing goals }\end{array}$ & $\mathrm{x}$ \\
\hline $\begin{array}{l}\text { Lillis, Magyar } \\
\text { and } \\
\text { Robinson- } \\
\text { Pant (2010) }\end{array}$ & $\begin{array}{l}\text { Academic } \\
\text { literacies } \\
\text { framework }\end{array}$ & $\begin{array}{l}\text { Writing, } \\
\text { rewriting } \\
\text { abstract } \\
\text { Hands on } \\
\text { mentors }\end{array}$ & $\begin{array}{l}\text { Clarifying the } \\
\text { style and nature } \\
\text { of writing }\end{array}$ & $\begin{array}{l}\text { Accepted } \\
\text { manuscripts }\end{array}$ & $\mathrm{x}$ \\
\hline $\begin{array}{l}\text { MacLeod, } \\
\text { Steckley and } \\
\text { Murray } \\
(2012)\end{array}$ & Containment & $\begin{array}{l}\text { Emotional } \\
\text { containment }\end{array}$ & Task primacy & Task primacy & $\begin{array}{l}\text { Epistemological } \\
\text { containment }\end{array}$ \\
\hline $\begin{array}{l}\text { Murray } \\
(2013)\end{array}$ & Engagement & $\begin{array}{l}\text { Cognitive, } \\
\text { emotional and } \\
\text { physical } \\
\text { engagement }\end{array}$ & $\begin{array}{l}\text { Cognitive, } \\
\text { emotional and } \\
\text { physical } \\
\text { engagement }\end{array}$ & $\begin{array}{l}\text { Research } \\
\text { output }\end{array}$ & $\mathrm{x}$ \\
\hline $\begin{array}{l}\text { Murray and } \\
\text { Thow (2014) }\end{array}$ & $\begin{array}{l}\text { Stages of } \\
\text { change }\end{array}$ & $\begin{array}{l}\text { Decisional } \\
\text { balance }\end{array}$ & Action planning & $\begin{array}{l}\text { Goal setting } \\
\text { and review }\end{array}$ & $\begin{array}{l}\text { Alignment with } \\
\text { institutional values }\end{array}$ \\
\hline $\begin{array}{l}\text { Dwyer et al. } \\
(2015)\end{array}$ & $\begin{array}{l}\text { Communities } \\
\text { of practice }\end{array}$ & $\begin{array}{l}\text { Minimize } \\
\text { anxiety about } \\
\text { writing }\end{array}$ & $\begin{array}{l}\text { Skill } \\
\text { development }\end{array}$ & $\mathrm{X}$ & $\mathrm{x}$ \\
\hline
\end{tabular}

${ }^{1}$ Performance belief: The academic's belief that they personally can perform the behaviours required to produce writing

${ }^{2}$ Process belief: The academics' belief that they are able to actively change the environment to produce writing.

${ }^{3}$ Prospect belief: The academics' belief that the desired outcome of the writing are achievable

${ }^{4}$ Profit belief: The academics' belief that achievement of these writing goals, i.e. publications, will

benefit them personally in some way 
Table 3. Writing programmes within systems approach

\begin{tabular}{|c|c|c|c|c|c|}
\hline $\begin{array}{l}\text { Authors } \\
\text { (year) }\end{array}$ & $\begin{array}{l}\text { Domain } \\
\text { Framework }\end{array}$ & Microsystem $^{1}$ & Mesosystem $^{2}$ & Exosystem $^{3}$ & Macrosystem $^{4}$ \\
\hline $\begin{array}{l}\text { Baldwin and } \\
\text { Chandler } \\
(2002)\end{array}$ & $\begin{array}{l}\text { Situational } \\
\text { leadership }\end{array}$ & Coach & $\begin{array}{l}\text { Situational } \\
\text { leadership and } \\
\text { coaching }\end{array}$ & $\begin{array}{l}\text { Supportive Dean } \\
\text { of Faculty: time }\end{array}$ & $\mathrm{x}$ \\
\hline $\begin{array}{l}\text { Jackson } \\
(2009)\end{array}$ & $\begin{array}{l}\text { Servant } \\
\text { leadership }\end{array}$ & $\begin{array}{l}\text { Mentors } \\
\text { Peer learning } \\
\text { partnerships }\end{array}$ & $\begin{array}{l}\text { Servant } \\
\text { leadership }\end{array}$ & $\begin{array}{l}\text { Time and money } \\
\text { to attend }\end{array}$ & $\mathrm{x}$ \\
\hline $\begin{array}{l}\text { Lillis, } \\
\text { Magyar and } \\
\text { Robinson- } \\
\text { Pant (2010) }\end{array}$ & $\begin{array}{l}\text { Academic } \\
\text { literacies } \\
\text { framework }\end{array}$ & $\begin{array}{l}\text { Editors evolve } \\
\text { to a } \\
\text { microsystem } \\
\text { rather than } \\
\text { macro only }\end{array}$ & $\mathrm{x}$ & $\mathrm{x}$ & $\begin{array}{l}\text { Cultural aspects of } \\
\text { the journal }\end{array}$ \\
\hline $\begin{array}{l}\text { MacLeod, } \\
\text { Steckley and } \\
\text { Murray } \\
(2012)\end{array}$ & Containment & $\mathrm{x}$ & Task primacy & $\begin{array}{l}\text { Organisational } \\
\text { containment } \\
\text { Task primacy }\end{array}$ & $\mathrm{x}$ \\
\hline $\begin{array}{l}\text { Murray } \\
(2013)\end{array}$ & Engagement & $\begin{array}{l}\text { Controlled } \\
\text { environment }\end{array}$ & $\begin{array}{l}\text { Like minded } \\
\text { participants }\end{array}$ & $\begin{array}{l}\text { Disengagement } \\
\text { from unhelpful } \\
\text { system }\end{array}$ & $\mathrm{x}$ \\
\hline $\begin{array}{l}\text { Murray and } \\
\text { Thow (2014) }\end{array}$ & $\begin{array}{l}\text { Stages of } \\
\text { change }\end{array}$ & Writing meeting & Peer facilitation & $\begin{array}{l}\text { Alignment with } \\
\text { institutional } \\
\text { values }\end{array}$ & $\mathrm{x}$ \\
\hline $\begin{array}{l}\text { Dwyer et al. } \\
(2015)\end{array}$ & $\begin{array}{l}\text { Communities } \\
\text { of practice }\end{array}$ & $\begin{array}{l}\text { Shared space, } \\
\text { time and writing } \\
\text { Secluded } \\
\text { location }\end{array}$ & $\begin{array}{l}\text { Group activities } \\
\text { Development of } \\
\text { reciprocal } \\
\text { 'obligation' for } \\
\text { support }\end{array}$ & $\mathrm{x}$ & $\begin{array}{l}\text { Feedback from } \\
\text { journal } \\
\text { reviewers/editors }\end{array}$ \\
\hline
\end{tabular}

${ }^{1}$ Microsystem: The relationships between the academic and their immediate work environment

${ }^{2}$ Mesosystem: The relationships between the people in the microsystem

${ }^{3}$ Exosystem: The Higher Education institution

${ }^{4}$ Macrosystem: Society, government structures and academic cultures 